\title{
Comparison of Blood Test Data Between Patients With COVID-19 and Influenza: a Retrospective Cross-sectional Survey in a Japanese University Hospital
}

Sayato Fukui ( $\nabla$ sfukui@juntendo.ac.jp )

Juntendo University Faculty of Medicine

Akihiro Inui

Juntendo University Faculty of Medicine

Mizue Saita

Juntendo University Faculty of Medicine

Daiki Kobayashi

St. Luke's International Hospital

Toshio Naito

Juntendo University Faculty of Medicine

\section{Research Article}

Keywords: COVID-19, SARS-CoV-2, influenza, clinical feature

Posted Date: June 10th, 2021

DOI: https://doi.org/10.21203/rs.3.rs-587613/v1

License: (c) (i) This work is licensed under a Creative Commons Attribution 4.0 International License.

Read Full License 


\section{Abstract}

Background: Characteristics features, including blood test data, of COVID-19 compared to those of influenza have not been defined.

Purpose: We aimed to compare clinical parameters, including blood test data, between COVID-19 and influenza.

Methods: This retrospective cross-sectional survey was conducted at Juntendo University Nerima Hospital, Tokyo, Japan. We recruited patients diagnosed with COVID-19 between January 1 and December 31, 2020, and all patients underwent blood tests. For comparison, we recruited patients diagnosed with influenza. The number of patients with influenza and those with COVID-19 was the same. All patients with influenza underwent blood tests and the period was dated back from December 31, 2020 until the period that was the same number of COVID-19.

Results: During the study period, 228 patients (male:female, 123 [54.0\%]:105 [46.0\%], age [mean \pm standard deviation], $54.68 \pm 18.98$ years) were diagnosed with COVID-19. We recruited the same number of influenza patients (228 patients; male:female, 129 [56.6\%]:99 [43.4\%], age [mean \pm standard deviation], 69.6 \pm 21.25 ). Age 15-70 years (vs. 71 years), difficulty in breathing, malaise, and percentage of lymphocytes $>20 \%$ were significantly more frequent in COVID-19. However, nausea, body temperature $>38.1^{\circ} \mathrm{C}$, and white blood cell count $>9000 / \mu \mathrm{L}$ were more frequent in influenza.

Conclusion: Our results are useful for differentiating COVID-19 from influenza.

\section{Introduction}

In December 2019, a series of pneumonia cases of unknown cause were reported, involving clinical presentations that greatly resembled those of viral pneumonia [1-3]. The coronavirus disease (COVID-19) pandemic has been a great threat to human life. Many case reports on the similarity between COVID-19 and influenza have been published [4-7], but the disease presentation continues to vary among individuals. Symptoms that are different from those seen in past viral infections have also been reported. For example, there are reports of patients presenting with major loss of smell and taste $[8,9]$. The wide range of features reported is thought to reflect effects on non-respiratory systems and indicate that signs may be observed in patients who are infected, but lack apparent respiratory symptoms [10].

Before 2019, influenza was one of the common infectious diseases considered a cause of fever, especially in seasonal epidemic. However, it is difficult to discriminate influenza from COVID-19 because more emphasis is being placed on COVID-19 diagnosis. As described above, in COVID-19, characteristic symptoms such as loss of smell and taste are reported $[8,9]$. Some studies have directly compared the burden of COVID-19 and influenza individually [11-14]. In a previous study, anosmia (53\% vs. $17 \%, p<$ $0.001)$, dysgeusia ( $49 \%$ vs. $20 \%, p=0.001)$, diarrhea ( $40 \%$ vs. $20 \%, p=0.021)$, frontal headache ( $26 \%$ vs. $9 \%, p=0.021)$, and bilateral crackling sounds ( $24 \%$ vs. $9 \%, p=0.034)$ were significantly more frequent in 
COVID-19 than in influenza. However, sputum production (52\% vs. $29 \%, p=0.010)$, dyspnea (59\% vs. $34 \%$, $p=0.007)$, sore throat ( $44 \%$ vs. $20 \%, p=0.006)$, conjunctival hyperemia (30\% vs. $4 \%, p<0.001)$, tearing ( $24 \%$ vs $6 \%, p=0.004)$, vomiting $(22 \%$ vs $3 \%, p=0.001)$, and rhonchi sounds $(17 \%$ vs. $1 \%, p=0.002)$ were more frequent in influenza than in COVID-19 [13]. However, studies comparing COVID-19 and influenza, using blood test data have not been conducted thus far. In a previous study, elevated red blood cell distribution width (RDW) at the time of hospital admission and an increase in RDW during hospitalization were associated with an increased risk of mortality in patients with COVID-19 [15]. In another study, the fibrinogen-to-albumin ratio and platelet count were independent risk factors for severe illness [16]. Thus, COVID-19 may be diagnosed based on not only clinical symptoms but also blood test data, and a comparison between COVID-19 and influenza using blood test data is thought have clinical significance. In influenza, physical examination is performed to examine characteristic features such as influenza follicles $[17,18]$, but the physical examination is often omitted after the COVID-19 outbreak. The results of this study will be useful for phylaxis purposes. Therefore, this cross-sectional study aimed to identify the characteristics of COVID-19 from blood test data and compare them with those of influenza.

\section{Methods}

\section{Study design and study population}

We recruited patients diagnosed with COVID-19 from January 1, 2020 to December 31, 2020, and all patients underwent blood tests. For comparison, we recruited patients diagnosed with influenza; the number of patients with influenza and those with COVID-19 was the same. All patients with influenza also underwent blood tests and the period was dated back from December 31, 2020 until the period that was the same number of COVID-19. Furthermore, children (aged < 14 years) with COVID-19 and influenza were excluded. COVID-19 was diagnosed using a polymerase chain reaction text for the detection of severe acute respiratory syndrome coronavirus 2 (SARS-CoV-2) nucleic acid, and influenza was diagnosed using a rapid influenza diagnostic kit. Furthermore, more than two doctors were involved in each diagnosis. This retrospective, cross-sectional study was performed at Juntendo University Nerima Hospital, a 490-bed university-affiliated hospital in Tokyo, Japan.

Clinical information was extracted by chart review. Data on the following variables were collected: age, sex, history of malignant diseases, asthma, heart disease including hypertension, diabetes mellitus, hemodyscrasia, human immunodeficiency virus infection, use of immunosuppressive agents (including steroids), and general symptoms (chills, sore throat, cough, headache, diarrhea, nausea, joint pain, malaise, and difficulty in breathing). We also extracted data on axillary body temperature, systolic and diastolic blood pressure, pulse rate, respiratory rate, oxygen saturation (room air), white blood cell (WBC) count along with the percentage of neutrophils and lymphocytes, hemoglobin level, platelet count, RDW, serum parameters (levels of total protein, albumin, lactate dehydrogenase, blood urea nitrogen, creatinine, sodium, potassium, chloride, glucose, aspartate aminotransferase, alanine aminotransferase, total bilirubin, glucose, hemoglobin A1c, and C-reactive protein [CRP]). 


\section{Statistical analysis}

Bivariate comparisons of each variable between COVID-19 and influenza were performed using independent samples $t$-tests for continuous data or chi-square tests for categorical data. Differences with $p$ values of $<0.05$ were defined as statistically significant. Variables with a $p$ value of $<0.05$ in bivariate analysis were entered into multivariable logistic regression models. The accuracy of the logistic regression models was assessed using the area under the curve (AUC) of the receiver operating characteristic (ROC) curve. All statistical analyses were performed using EZR (Saitama Medical Center; Jichi Medical University, Saitama, Japan), a graphical user interface for R (The R Foundation for Statistical Computing, Vienna, Austria). EZR is a modified version of R Commander designed to add statistical functions frequently used in biostatistics [19].

This study was conducted in accordance with relevant guidelines and regulations. This retrospective study was approved by the ethics committee of Juntendo University Nerima Hospital, Tokyo, Japan (approval number: 2020066).

\section{Results}

During the study period, 228 patients (male:female, 123 [54.0\%]:105 [46.0\%], age [mean \pm standard deviation $\{S D\}$ ] $54.68 \pm 18.98$ ) were diagnosed with COVID-19. The number of patients with influenza (228 patients; male:female, 129 [56.6\%]:99 [43.4\%], age [mean \pm SD] $69.6 \pm 21.25)$ was the same as that of patients with COVID-19. Patients with influenza were recruited between January 11, 2015 and December 31, 2020. All influenza patients were classified as having type A disease. As shown in Table 1, a total of 456 patients (male:female, 252 [55.3\%]:204 [44.7\%]; mean \pm SD age, 62.12 \pm 21.47 years) were included in this study. Table 1 shows the characteristics of patients with COVID-19 and influenza and the results of the bivariable analysis. Age, cancer, asthma, heart diseases, difficulty in breathing, chills, nausea, malaise, body temperature, systolic blood pressure, heart rate, respiratory rate, saturation, WBC count, percentage of neutrophils, percentage of lymphocytes, hemoglobin level, RDW, platelet count, aspartate aminotransferase level, sodium level, chloride level, CRP level, creatine phosphokinase level, and creatine phosphokinase level were significantly different between the groups (Table 1). We conducted multivariable logistic regression analysis based on bivariable analysis (Table 2). The following variables were considered for multivariable regression analysis: age, chills, difficulty in breathing, nausea, malaise, body temperature, WBC count, percentage of lymphocytes, and creatine phosphokinase level. We incorporated these factors as they are thought to be clinically useful. For example, chloride, we excluded the factor which a significant difference was over in normal range even if significantly different. Based on the cutoff value, body temperature was categorized as hypothermia $\left(<35.9^{\circ} \mathrm{C}\right)$ and hyperthermia $(>$ $38.1^{\circ} \mathrm{C}$ ), and a body temperature of $36^{\circ} \mathrm{C}-38^{\circ} \mathrm{C}$ was used as the reference range. Furthermore, the cutoff WBC count was $>9000 / \mu \mathrm{L}$, which was higher than the normal upper limit. For a similar reason, the cutoff value for the percentage of lymphocytes was $>20 \%$, and that for the creatine phosphokinase level were $>$ $300 \mathrm{U} / \mathrm{L}$. Because the percentage of neutrophils and lymphocytes was highly correlated with each other, the percentage of lymphocytes was used in multivariable analysis as a representative of these two 
variables. The significant factors in multivariable analysis were age $15-70$ years (vs. 71 years) (odds ratio $[O R]=5.53,95 \%$ confidence interval $[\mathrm{Cl}]$ : $2.86-10.70, \mathrm{p}<0.001)$, difficulty in breathing $(\mathrm{OR}=3.20$, $95 \% \mathrm{Cl}: 1.37-7.47, \mathrm{p}<0.01)$, nausea (OR $=0.10,95 \% \mathrm{Cl}: 0.01-0.97, \mathrm{p}=0.04)$, malaise $(\mathrm{OR}=2.43,95 \% \mathrm{Cl}$ : $1.06-5.53, p=0.03)$, body temperature $>38.1^{\circ} \mathrm{C}(\mathrm{OR}=0.07,95 \% \mathrm{Cl}: 0.03-0.14, \mathrm{p}<0.001)$, WBC count $>$ $9000 / \mu \mathrm{L}(\mathrm{OR}=0.12,95 \% \mathrm{Cl}: 0.03-0.43, \mathrm{p}<0.001)$, and percentage of lymphocytes $>20 \%(\mathrm{OR}=3.74,95 \%$ $\mathrm{Cl}: 1.91-7.31, p<0.001)$. We evaluated the quality of this model using the discrimination of ROC-AUC; the ROC-AUC was 0.922 (95\% Cl: 0.89-0.95). Thus, the model used in this study had sufficient power. 
Table 1

Patient variables and results of univariate analysis

Total

Variables

Demographic factors

Age, years, mean $\pm S D$

Female sex, n, \%

Underlying condition

Cancer, $n, \%$

$45(9.8 \%)$

$13(5.7 \%)$

$32(14.0 \%)$

$\chi^{2}$

$3(1.3 \%)$

$8(3.5 \%)$

$26(11.4 \%)$

$29(12.7 \%)$

$29(12.7 \%) \quad 12(5.2 \%)$

$41(8.9 \%)$

$152(33.3 \%)$

$61(26.7 \%)$

$91(39.9 \%)$

$\chi^{2}$

$\chi^{2}$

$\chi^{2}$

$x^{2}$

$0.01^{*}$

Heart disease, n, \%

Human immunodeficiency

syndrome, $n, \%$

Use of immunosuppressive agents, $n, \%$

Smoker, $\mathrm{n}, \%$

\section{Symptoms}

Headache, n, \%

Cough, n, \%

Sore throat, n, \%

Difficulty in breathing, $n, \%$

Chill, n, \%

Joint pain, $n, \%$

COVID-19, coronavirus disease; SD, standard deviation $\underset{\text { value }}{p}$

Test

performed 


\begin{tabular}{|c|c|c|c|c|c|}
\hline \multirow[b]{2}{*}{ Variables } & \multirow{2}{*}{$\begin{array}{l}\text { Total } \\
\mathrm{n}=\mathbf{4 5 6}\end{array}$} & \multirow{2}{*}{$\begin{array}{l}\text { COVID-19 } \\
n=228\end{array}$} & \multicolumn{2}{|l|}{ Influenza } & \multirow{2}{*}{$\begin{array}{l}p \\
\text { value }\end{array}$} \\
\hline & & & $n=228$ & $\begin{array}{l}\text { Test } \\
\text { performed }\end{array}$ & \\
\hline Nausea, n, \% & $24(5.3 \%)$ & $3(1.3 \%)$ & 21 (9.2\%) & $x^{2}$ & $<.001 *$ \\
\hline Diarrhea, n, \% & $24(5.3 \%)$ & $14(6.1 \%)$ & $10(4.3 \%)$ & $x^{2}$ & 0.53 \\
\hline Malaise, n, \% & $105(23.0 \%)$ & $71(31.1 \%)$ & $34(14.9 \%)$ & $\chi^{2}$ & $\dot{0} 001 *$ \\
\hline \multicolumn{6}{|l|}{ Vital signs } \\
\hline Body temperature, ${ }^{\circ} \mathrm{C}, \pm \mathrm{SD}$ & $37.57 \pm 1.10$ & $36.93 \pm 0.76$ & $38.22 \pm 1.00$ & t-test & $<.001 *$ \\
\hline $\begin{array}{l}\text { Systolic blood pressure, } \\
\mathrm{mmHg}, \pm S D\end{array}$ & $\begin{array}{l}134.44 \pm \\
24.05\end{array}$ & $\begin{array}{l}128.21 \pm \\
19.82\end{array}$ & $\begin{array}{l}141.01 \pm \\
26.31\end{array}$ & t-test & $<.001 *$ \\
\hline $\begin{array}{l}\text { Diastolic blood pressure, } \\
\mathrm{mmHg} \pm \text { SD }\end{array}$ & $\begin{array}{l}79.47 \pm \\
14.97\end{array}$ & $\begin{array}{l}79.36 \pm \\
14.34\end{array}$ & $\begin{array}{l}79.59 \pm \\
15.65\end{array}$ & t-test & 0.88 \\
\hline Heart rate, bpm, $\pm S D$ & $\begin{array}{l}90.85 \pm \\
18.00\end{array}$ & $\begin{array}{l}85.00 \pm \\
15.82\end{array}$ & $\begin{array}{l}96.94 \pm \\
18.14\end{array}$ & t-test & $<.001 *$ \\
\hline Respiratory rate, $n, \pm S D$ & $18.08 \pm 3.92$ & $17.25 \pm 3.24$ & $18.96 \pm 4.37$ & t-test & $<.001 *$ \\
\hline Saturation, $\%, \pm S D$ & $95.39 \pm 3.82$ & $95.85 \pm 3.59$ & $94.90 \pm 4.00$ & t-test & $<.01 *$ \\
\hline \multicolumn{6}{|l|}{ Laboratory data } \\
\hline $\begin{array}{l}\text { White blood cell counts, } / \mu \mathrm{L} \text {, } \\
\pm S D\end{array}$ & $\begin{array}{l}6249.34 \pm \\
3003.32\end{array}$ & $\begin{array}{l}5249.12 \pm \\
2269.90\end{array}$ & $\begin{array}{l}7249.56 \pm \\
3304.15\end{array}$ & t-test & $<.001 *$ \\
\hline Neutrophils, $\%, \pm S D$ & $\begin{array}{l}68.81 \pm \\
15.14\end{array}$ & $\begin{array}{l}63.81 \pm \\
14.32\end{array}$ & $\begin{array}{l}75.32 \pm \\
13.67\end{array}$ & t-test & $<.001 *$ \\
\hline Lymphocytes, \%, „SD & $\begin{array}{l}21.33 \pm \\
12.47\end{array}$ & $\begin{array}{l}26.49 \pm \\
11.78\end{array}$ & $14.60 \pm 9.89$ & t-test & $<.001 *$ \\
\hline Hemoglobin, g/dL, \pm SD & $13.79 \pm 1.72$ & $13.96 \pm 1.93$ & $13.62 \pm 1.48$ & t-test & $0.04 *$ \\
\hline $\begin{array}{l}\text { Red blood cell distribution } \\
\text { width, \%, } \pm S D\end{array}$ & $15.18 \pm 4.65$ & $12.84 \pm 1.47$ & $17.52 \pm 5.49$ & t-test & $<.001 *$ \\
\hline Platelet, $10^{4} / \mu \mathrm{L}, \pm \mathrm{SD}$ & $17.46 \pm 7.70$ & $21.51 \pm 9.07$ & $13.42 \pm 1.95$ & t-test & $<.001 *$ \\
\hline $\begin{array}{l}\text { Blood urea nitrogen, } \mathrm{mg} / \mathrm{dL} \text {, } \\
\pm \mathrm{SD}\end{array}$ & $\begin{array}{l}16.86 \pm \\
13.38\end{array}$ & $\begin{array}{l}15.88 \pm \\
13.79\end{array}$ & $\begin{array}{l}17.84 \pm \\
12.92\end{array}$ & t-test & 0.12 \\
\hline
\end{tabular}




\begin{tabular}{|c|c|c|c|c|c|}
\hline & Total & COVID-19 & Influenza & & $p$ \\
\hline Variables & $n=456$ & $\mathrm{n}=\mathbf{2 2 8}$ & $\mathrm{n}=\mathbf{2 2 8}$ & $\begin{array}{l}\text { Test } \\
\text { performed }\end{array}$ & \\
\hline Creatinine, $\mathrm{mg} / \mathrm{dL}, \pm \mathrm{SD}$ & $1.02 \pm 1.07$ & $0.95 \pm 0.79$ & $1.09 \pm 1.29$ & t-test & 0.16 \\
\hline Total protein, $\mathrm{g} / \mathrm{dL}, \pm \mathrm{SD}$ & $7.08 \pm 0.68$ & $7.08 \pm 0.69$ & $7.08 \pm 0.67$ & t-test & 0.92 \\
\hline Albumin, $\mathrm{g} / \mathrm{dL}, \pm S \mathrm{SD}$ & $3.92 \pm 0.59$ & $3.97 \pm 0.60$ & $3.86 \pm 0.57$ & t-test & 0.07 \\
\hline Total bilirubin, $\mathrm{g} / \mathrm{dL}, \pm S D$ & $0.60 \pm 0.45$ & $0.57 \pm 0.52$ & $0.64 \pm 0.34$ & t-test & 0.09 \\
\hline $\begin{array}{l}\text { Lactate dehydrogenase, IU/L, } \\
\pm S D\end{array}$ & $\begin{array}{l}252.56 \pm \\
103.54\end{array}$ & $\begin{array}{l}246.76 \pm \\
101.40\end{array}$ & $\begin{array}{l}258.76 \pm \\
105.67\end{array}$ & t-test & 0.23 \\
\hline $\begin{array}{l}\text { Aspartate aminotransferase, } \\
\text { IU/L, } \pm S D\end{array}$ & $\begin{array}{l}35.30 \pm \\
31.46\end{array}$ & $\begin{array}{l}32.26 \pm \\
22.57\end{array}$ & $\begin{array}{l}38.36 \pm \\
38.15\end{array}$ & t-test & $0.04^{\star}$ \\
\hline $\begin{array}{l}\text { Alanine aminotransferase, } \\
I U / L, \pm S D\end{array}$ & $\begin{array}{l}30.04 \pm \\
32.72\end{array}$ & $\begin{array}{l}32.76 \pm \\
38.48\end{array}$ & $\begin{array}{l}27.32 \pm \\
25.85\end{array}$ & t-test & 0.08 \\
\hline Sodium, $\mathrm{mEq} / \mathrm{L}, \pm \mathrm{SD}$ & $\begin{array}{l}137.39 \pm \\
3.90\end{array}$ & $\begin{array}{l}138.39 \pm \\
3.51\end{array}$ & $\begin{array}{l}136.38 \pm \\
4.01\end{array}$ & t-test & $<.001^{*}$ \\
\hline Potassium, mEq/L, \pm SD & $4.06 \pm 0.52$ & $4.07 \pm 0.46$ & $4.05 \pm 0.61$ & t-test & 0.79 \\
\hline Chloride, $\mathrm{mEq} / \mathrm{L}, \pm \mathrm{SD}$ & $\begin{array}{l}102.30 \pm \\
4.06\end{array}$ & $\begin{array}{l}103.36 \pm \\
3.85\end{array}$ & $\begin{array}{l}101.24 \pm \\
3.99\end{array}$ & t-test & $<.001 *$ \\
\hline $\begin{array}{l}\text { C reactive protein, } \mathrm{mg} / \mathrm{dL}, \\
\pm S D\end{array}$ & $3.88 \pm 5.54$ & $3.19 \pm 4.66$ & $4.56 \pm 6.23$ & t-test & $<0.01 *$ \\
\hline $\begin{array}{l}\text { Creatine phosphokinase, } U / L \text {, } \\
\pm S D\end{array}$ & $\begin{array}{l}305.56 \pm \\
1391.28\end{array}$ & $\begin{array}{l}121.44 \pm \\
198.79\end{array}$ & $\begin{array}{l}500.25 \pm \\
1968.86\end{array}$ & t-test & $<.01 *$ \\
\hline Glucose, mg/dL, \pm SD & $\begin{array}{l}120.08 \pm \\
38.22\end{array}$ & $\begin{array}{l}113.76 \pm \\
36.53\end{array}$ & $\begin{array}{l}128.13 \pm \\
38.90\end{array}$ & t-test & $<.001 *$ \\
\hline Hemoglobin A1c, \%, \pm SD & $6.10 \pm 0.92$ & $6.04 \pm 0.87$ & $6.30 \pm 1.04$ & t-test & 0.06 \\
\hline \multicolumn{6}{|l|}{${ }^{\star} p<0.05$} \\
\hline COVID-19, coronavirus diseas & , sta & Ition & & & \\
\hline
\end{tabular}


Table 2

Multivariable logistic regression model

\begin{tabular}{|llll|}
\hline Variables & $\begin{array}{l}\text { Multivariable } \\
\text { OR }\end{array}$ & $\begin{array}{l}\text { Multivariable 95\% } \\
\text { Cl }\end{array}$ & $\begin{array}{l}\text { Multivariable } p \text { - } \\
\text { value }\end{array}$ \\
\hline Age $15-70$ (vs. 71 ) years & 5.53 & $2.86-10.70$ & $<0.001^{*}$ \\
\hline Chills & 0.77 & $0.20-2.97$ & 0.71 \\
\hline Difficulty in breathing & 3.20 & $1.37-7.47$ & $<0.01^{*}$ \\
\hline Nausea & 0.10 & $0.01-0.97$ & $0.04^{*}$ \\
\hline Malaise & 2.43 & $1.06-5.53$ & $0.03^{*}$ \\
\hline Body temperature $<35.9^{\circ} \mathrm{C}$ & 1.91 & $0.20-18.13$ & 0.57 \\
\hline $36.0-38.0^{\circ} \mathrm{C}$ & $\square$ & Reference & $\square$ \\
\hline$>38.1^{\circ} \mathrm{C}$ & 0.07 & $0.03-0.14$ & $<0.001^{*}$ \\
\hline White blood cell count $>9000 / \mu \mathrm{L}$ & 0.12 & $0.03-0.43$ & $<0.01^{*}$ \\
\hline Lymphocyte $>20 \%$ & 3.74 & $1.91-7.31$ & $<0.001^{*}$ \\
\hline $\begin{array}{l}\text { Creatine phosphokinase }>300 \\
\text { U/L }\end{array}$ & 0.69 & $0.24-1.94$ & 0.48 \\
\hline$* p<0.05$ & & & \\
\hline OR, odds ratio; Cl, confidence interval & & \\
\hline
\end{tabular}

\section{Discussion}

To the best of our knowledge, this is the first study to directly compare patients with COVID-19 and influenza using laboratory test data in a university hospital. Age 15-70 years (vs. 71 years), difficulty in breathing, malaise, and percentage of lymphocyte $>20 \%$ were significantly more frequent in patients with COVID-19 than in those with influenza. However, nausea, body temperature $>38.1^{\circ} \mathrm{C}$, and WBC count $>$ $9000 / \mu \mathrm{L}$ were more frequent in patients with influenza than in those with COVID-19.

Other studies have reported that age at the onset of COVID-19 is lower than that at the onset of influenza $[14,20]$. The results of these studies support the results of the present study.

SARS-CoV-2 mainly invades respiratory epithelial cells by adhesion to angiotensin-converting enzyme 2; thus, infected patients may develop mild-to-severe inflammatory responses and acute lung injury [21]. Another study has reported that COVID-19 causes acute respiratory failure in the predominance of influenza [14]. These studies support the results of our study, revealing a higher number of cases of dyspnea cases than those of influenza. 
Similarly, malaise is a symptom that has been reported in many patients with COVID-19 [14]. According to a previous study, 63\% patients with COVID-19 have malaise [22]. These studies support the results of our study, revealing a higher number of cases of malaise than those of influenza cases. Malaise may be related to an increase in viral load and immune response to the infection [23]. In addition, insufficient energy production to meet the required metabolic demands is related to malaise [24].

Many studies have reported low lymphocyte counts in patients with COVID-19 [25, 26]. The host immune responses strongly try to involve all potential cells and cytokines. In chronic COVID-19 cases, natural killer cells and $T$ cells become exhausted, and a decrease in their count leads to lymphopenia. The inability to eradicate the infection in the affected organ causes hyper-initiation of the immune system, which releases excessive amounts of inflammatory cytokines to compensate for the exhausted ones and the low lymphocyte count [25]. Similarly, a low lymphocyte count has been reported in influenza [27, 28]. However, our study shows that the lymphocyte counts are lower in in patients with COVID-19 than in patients with influenza. Furthermore, regarding WBC count, a study has shown that low leukocyte counts are markers of COVID-19 [29]. In our study, WBC counts $>9000 / \mu \mathrm{L}$ were more frequently associated with influenza than with COVID-19. This finding suggests the likelihood of it being useful for the differentiation of COVID-19 from influenza. In addition, our study showed that CRP levels are not useful for the differentiation of COVID-19 from influenza. Similarly, a previous study showed that CRP levels were not an effective discriminator of COVID-19 and non-COVID-19 cases [29]. However, a significantly higher level of CRP was observed in the severe COVID-19 group than in the non-COVID-19 group, which confirms the findings of previous studies regarding the clinical utility of CRP levels as an indicator of severe disease and progressive inflammation [30, 31]. In our study, a significant difference in CRP levels was possibly not observed because none of the patients with COVID-19 had severe disease. In contrast to a previous meta-analysis [32], a recent meta-analysis revealed that procalcitonin levels were not significantly different between the severe and non-severe groups. The procalcitonin level was only assessed in a few cases in this study; therefore, we did not add this in the extraction item; however, we think that it is the contents that procalcitonin level may be argued comparison between COVID-19 and influenza in the future.

Body temperature $>38.1^{\circ} \mathrm{C}$ was more frequent in patients with influenza than in those with COVID-19. Many cases not involving fever have been reported in COVID-19 [33,34]. We believe that these findings support our results. However, the result may be effects that patients receiving antipyretics could not be excluded. Furthermore, many patients with COVID-19 had to be hospitalized for isolation owing to the high infectious control, and they underwent laboratory tests even if they were asymptomatic.

Nausea is more frequently associated with influenza than with COVID-19. In a study, nausea occurred in approximately 3.9\% patients with COVID-19 [33]. Similarly, the ratio of nausea is unknown, but it can cause digestive symptoms including nausea in influenza. The mechanism to cause nausea is unclear and requires further investigation. Inflammatory reactions may occur when a virus infects gastrointestinal mucosal bleeding cells, and digestive symptoms such as nausea are thought to occur during these reactions. In this study, significantly fewer symptoms of nausea in patients with COVID-19 may reflect the 
greater strength of the respiratory tract infection than the gastrointestinal cells of COVID-19. Difficulty in breathing was significantly more frequent in patients with COVID-19 than in those with influenza, which may support our hypothesis.

There are some limitations to this study. First, there is a greater possibility that patients with COVID-19 are hospitalized as per law in Japan. Many patients with COVID-19 are hospitalized for isolation, which can help in controlling the spread of the highly infectious disease, even if present in young and asymptomatic patients. Furthermore, an influenza extraction period of several years passed (from December 31, 2020 to January 11, 2015). Annually, the seasonal flu may vary in symptoms, and this effect may have influenced the results of our study. However, the type of influenza did not influence the results, as there were no patients with influenza type B who underwent blood tests. In addition, we did not extract the data of three symptoms (taste disturbance, dysosmia, and conjunctival hyperemia) as they were inaccurate; therefore, these symptoms were not included in the chart review of patients with influenza. Finally, the patient population enrolled in this study was limited to that from a single hospital. Additionally, this was a retrospective study. Hence, a multicenter prospective study should be conducted with a larger number of patients to verify our results.

In conclusion, our results are useful for differentiating patients with COVID-19 from those with influenza. Age 15-70 years (vs. 71 years) years, difficulty in breathing, malaise, and percentage of lymphocytes > $20 \%$ were significantly more frequent in COVID-19 than in influenza. However, nausea, body temperature $>38.1^{\circ} \mathrm{C}$, and WBC counts $>9000 / \mu \mathrm{L}$ were more frequent in influenza than in COVID-19.

\section{Declarations}

\section{Ethics approval and consent to participate}

The Ethics Committee of Juntendo University Nerima Hospital approved this study (Approval Number 2020066). This study was an observational study and written informed consent was waived due to a public health outbreak investigation by the Ethics Commission (Juntendo University Nerima Hospital).

\section{Consent for publication}

All authors agreed to publish this study.

\section{Availability of data and materials}

The datasets used and/or analyzed during the current study available from the corresponding author on reasonable request.

\section{Competing interests}

Nothing to disclose for all authors 
This research received no specific grant from any funding agency in the public, commercial or not-forprofit sectors.

\section{Authors' contributions}

SF, Al, MS and TN contributed to study concept and design. SF and Al were involved in acquisition of participants and data. SF and DK were involved in analysis and interpretation of data. SF, Al, MS, DK and TN were involved in preparation of the manuscript.

\section{Acknowledgments}

None

\section{References}

1. Epidemiology Working Group for NCIP Epidemic Response, Chinese Center for Disease Control and Prevention. The epidemiological characteristics of an outbreak of 2019 novel coronavirus diseases (COVID-19) in China. Zhonghua Liu Xing Bing Xue Za Zhi 2020;41:145-51. doi: 10.3760/cma.j.issn.0254-6450.2020.02.003.

2. Wu JT, Leung K, Leung GM. Nowcasting and forecasting the potential domestic and international spread of the 2019-nCoV outbreak originating in Wuhan, China: a modelling study. Lancet 2020;395:689-97. doi: 10.1016/S0140-6736(20)30260-9.

3. Li Q, Guan X, Wu P, Wang X, Zhou L, Tong Y, et al. Early transmission dynamics in Wuhan, China, of novel coronavirus-infected pneumonia. N Engl J Med 2020;382:1199-207. doi: 10.1056/NEJMoa2001316.

4. Wu Z, McGoogan JM. Characteristics of and important lessons from the coronavirus disease 2019 (COVID-19) Outbreak in China: summary of a report of 72314 cases from the Chinese Center for Disease Control and Prevention. JAMA 2020;323:1239-42. doi: 10.1001/jama.2020.2648.

5. Pongpirul WA, Pongpirul K, Ratnarathon AC, Prasithsirikul W. Journey of a Thai taxi driver and novel coronavirus. N Engl J Med 2020;382:1067-68. doi: 10.1056/NEJMc2001621.

6. Chang C, Lin M, Wei L, Xie L, Zhu G, Dela Cruz, et al. Epidemiologic and clinical characteristics of novel coronavirus infections involving 13 patients outside Wuhan, China. JAMA 2020;323:1092-3. doi:10.1001/jama.2020.1623.

7. Liu YC, Liao CH, Chang CF, Chou CC, Lin YR. A locally transmitted case of SARS-CoV-2 infection in Taiwan. N Engl J Med 2020;382:1070-2. doi: 10.1056/NEJMc2001573.

8. Spinato G, Fabbris C, Polesel J, Cazzador D, Borsetto D, Hopkins C, et al. Alterations in smell or taste in mildly symptomatic outpatients with SARS-CoV-2 infection. JAMA 2020;323:2089-90. doi: 10.1001/jama.2020.6771.

9. Giacomelli A, Pezzati L, Conti F, Bernacchia D, Siano M, Oreni L, et al. Self-reported olfactory and taste disorders in patients with severe acute respiratory coronavirus 2 infection: a cross-sectional 
study. Clin Infect Dis 2020;71:889-90. doi: 10.1093/cid/ciaa330.

10. Wu P, Duan F, Luo C, Liu Q, Qu X, Liang L, et al. Characteristics of ocular findings of patients with coronavirus disease 2019 (COVID-19) in Hubei Province, China. JAMA Ophthalmol 2020;138:575-8. doi: 10.1001/jamaophthalmol.2020.1291.

11. Burn E, You SC, Sena AG, Kostka K, Abedtash H, Abrahão MTF, et al. An international characterisation of patients hospitalised with COVID-19 and a comparison with those previously hospitalised with influenza. medRxiv 2020. doi: 10.1101/2020.04.22.20074336 [Preprint].

12. Verity R, Okell LC, Dorigatti I, Winskill P, Whittaker C, Imai N, et al. Estimates of the severity of coronavirus disease 2019: a model-based analysis. Lancet Infect Dis 2020;20:669-77. doi: 10.1016/S1473-3099(20)30243-7.

13. Zayet S, Kadiane-Oussou NJ, Lepiller Q, Zahra H, Royer P-Y, Toko L, et al. Clinical features of COVID19 and influenza: a comparative study on Nord Franche- comte cluster. Microbes Infect 2020;22:481-88. doi: 10.1016/j.micinf.2020.05.016.

14. Piroth L, Cottenet J, Mariet AS, Bonniaud P, Blot M, Tubert-Bitter P, et al. Comparison of the characteristics, morbidity, and mortality of COVID-19 and seasonal influenza: a nationwide, population-based retrospective cohort study. Lancet Respir Med 2021;9:251-9. doi: 10.1016/S22132600(20)30527-0.

15. Foy BH, Carlson JCT, Reinertsen E, Padros I Valls R, Pallares Lopez R, Palanques-Tost E, et al. Association of red blood cell distribution width with mortality risk in hospitalized adults with SARSCoV-2 infection. JAMA Netw Open 2020 09;3:e2022058. doi: 10.1001/jamanetworkopen.2020.22058.

16. Bi X, Su Z, Yan Haixi, Du J, Wang J, Chen L, et al. Prediction of severe illness due to COVID-19 based on an analysis of initial fibrinogen to albumin ratio and platelet count. Platelets 2020;31:674-9. doi: 10.1080/09537104.2020.1760230.

17. Tomoda Y, Toya M, Kagawa S, Tanaka K. Influenza follicles. Intern Med 2019;58:2269. doi: 10.2169/internalmedicine.2573-18.

18. Kenzaka T, Kyotani M, Goda K, Akita H. Reply to 'Influenza follicles and their buds as early diagnostic markers of influenza: typical images' and demonstration of lymphoid follicles in the posterior pharyngeal walls of patients with mycoplasmal pneumonia. Postgrad Med J 2018;94:311-2. doi: 10.1136/postgradmedj-2017-135540.

19. Kanda Y. Investigation of the freely available easy-to-use software 'EZR' for medical statistics. Bone Marrow Transplant 2013;48:452-8. doi: 10.1038/bmt.2012.244.

20. Auvinen R, Nohynek H, Syrjänen R, Ollgren J, Kerttula T, Mäntylä J, et al. Comparison of the clinical characteristics and outcomes of hospitalized adult COVID-19 and influenza patients - a prospective observational study. Infect Dis (Lond) 2021;53:111-21. doi: 10.1080/23744235.2020.1840623.

21. Nouri-Vaskeh M, Sharifi A, Khalili N, Zand Ramin, Sharifı A. Dyspneic and non-dyspneic (silent) hypoxemia in COVID-19: possible neurological mechanism. Clin Neurol Neurosurg 2020;198:106217. doi: 10.1016/j.clineuro.2020.106217. 
22. Tostmann A, Bradley J, Bousema T, Yiek WK, Holwerda M, Bleeker-Rovers C, et al. Strong associations and moderate predictive value of early symptoms for SARS-CoV-2 test positivity among healthcare workers, the Netherlands, March 2020. Euro Surveill 2020;25. doi: 10.2807/15607917.ES.2020.25.16.2000508.

23. Brann DH, Tsukahara T, Weinreb C, Logan DW, Datta SR. Non-neural expression of SARS-CoV-2 entry genes in the olfactory epithelium suggests mechanisms underlying anosmia in COVID-19 patients. Sci Adv. 2020 Jul 31;6(31):eabc5801.doi: 10.1126/sciadv.abc5801. Epub 2020 Jul 24.

24. Recalcati S. Cutaneous manifestations in COVID-19: a first perspective. J Eur Acad Dermatol Venereol 2020;34:e212-3. doi: 10.1111/jdv.16387.

25. Fathi N, Rezaei N. Lymphopenia in COVID-19: therapeutic opportunities. Cell Biol Int 2020;44:1792-7. doi: 10.1002/cbin.11403.

26. Henry BM. COVID-19, ECMO, and lymphopenia: a word of caution. Lancet Respir Med 2020;8:e24. doi: 10.1016/S2213-2600(20)30119-3.

27. Lalueza A, Folgueira D, Díaz-Pedroche $C$, Hernández-Jiménez P, Ayuso B, Castillo $C$, et al. Severe lymphopenia in hospitalized patients with influenza virus infection as a marker of a poor outcome. Infect Dis (Lond) 2019;51:543-6. doi: 10.1080/23744235.2019.1598572.

28. Cunha BA, Pherez FM, Schoch P. Diagnostic importance of relative lymphopenia as a marker of swine influenza (H1N1) in adults. Clin Infect Dis 2009;49:1454-6. doi: 10.1086/644496.

29. Soraya GV, Ulhaq ZS. Crucial laboratory parameters in COVID-19 diagnosis and prognosis: an updated meta-analysis. Med Clin (Engl Ed) 2020;155:143-51. doi: 10.1016/j.medcle.2020.05.004.

30. Lo IL, Lio CF, Cheong HH, Lei Cl, Cheong TH, Zhong X, Tian Y, Sin NN. Evaluation of SARS-CoV-2 RNA shedding in clinical specimens and clinical characteristics of 10 patients with COVID-19 in Macau. Int J Biol Sci 2020;16:1698-707. doi: 10.7150/ijbs.45357.

31. Ruan Q, Yang K, Wang W, Jiang L, Song J. Clinical predictors of mortality due to COVID-19 based on an analysis of data of 150 patients from Wuhan, China. Intensive Care Med 2020;46:846-8. doi: 10.1007/s00134-020-05991-x.

32. Lippi G, Plebani M. Procalcitonin in patients with severe coronavirus disease 2019 (COVID-19): a meta-analysis. Clin Chim Acta 2020;505:190-1. doi: 10.1016/j.cca.2020.03.004.

33. Gao Z, Xu Y, Sun C, Wang X, Guo Y, Qiu S, et al. A systematic review of asymptomatic infections with COVID-19. J Microbiol Immunol Infect 2021;54:12-6. doi: 10.1016/j.jmii.2020.05.001.

34. Stadler RN, Maurer L, Aguilar-Bultet L, Franzeck F, Ruchti C, Kühl R, et al. Systematic screening on admission for SARS-CoV-2 to detect asymptomatic infections. Antimicrob Resist Infect Control 2021;10:44. doi: 10.1186/s13756-021-00912-z.

\section{Figures}




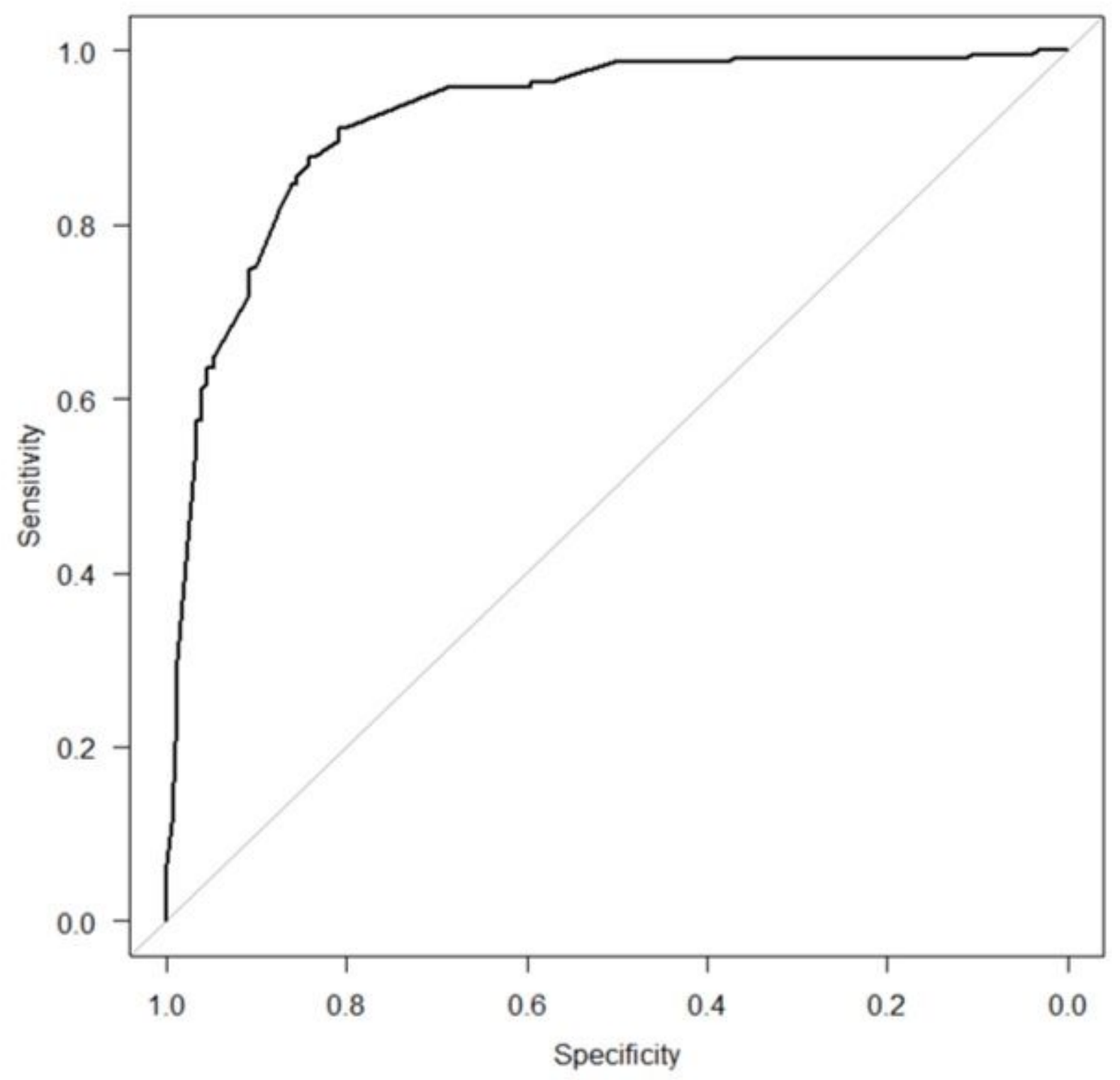

Figure 1

The area under the receiver operating characteristic curve of the model was 0.922 (95\% confidence interval: 0.89-0.95). 